\title{
The Content of Selenium and Its Chemical Form in Rain Water and Aerosol in Tokyo
}

\author{
By Yoshimi Suzuki, Yukio Sugimura and Yasuo Miyake* \\ Meteorological Research Institute, 1-1, Nagamine, Yatabe-machi, Tsukuba-gun, \\ Ibaraki-ken 305, Japan \\ (Manuscript received 30 July 1980, in revised form 26 February 1981) \\ * Geochemistry Research Association, Koenji-kita, Suginami-ku, Tokyo 166, Japan.
}

\begin{abstract}
Selenium content and its chemical form in rain water and aerosol in Tokyo was studied during the period from June 1975 through the end of 1977. Analysis of selenium was carried out by fluorometric method. The content of total selenium in rain water ranged from $5 \mathrm{ng}$ $1^{-1}$ to $118 \mathrm{ng} 1^{-1}$ with an average value of $69 \mathrm{ng} 1^{-1}$. Most of selenium in rain water was in tetravalent state which occupied 0.5 to 0.9 in the total. And the rest of selenium in rain water was present in particulate forms.

On the other hand, the content of selenium in aerosol in Tokyo ranged from $1.7 \mathrm{ng} \mathrm{m}^{-3}$ to $4.2 \mathrm{ng} \mathrm{m}^{-3}$ with an average of $3.0 \mathrm{ng} \mathrm{m}^{-3}$. It was found that the chemical form in a water soluble part of selenium in aerosol is tetravalent ion, and its ratio to total is 0.5 to 0.6 .
\end{abstract}

\section{Introduction}

Selenium is one of the sulfur group elements, but the occurrence and behavior of selenium in the environment is much different from sulfur (Bertine and Goldberg, 1971; Weiss, et al., 1971). Up to now, many studies on sulfur in the atmosphere and rain-fall have been done. However only few studies on selenium (Rancitelli et al., 1970; Hashimoto et al., 1971) have been published, because of the difficulty of the method of determination of minor quantity of selenium in water and in the air. Recently the present authors developed a new method of analysis of selenium in the environmental substances (Sugimura and Suzuki, 1977). Using this method the present authors carried out the analysis of selenium in different chemical forms in rain water and aerosol in Tokyo collected during the period from June 1975 to December 1977. In this paper, the results of observations are presented with some discussions.

\section{Sampling and a method of analysis}

Sampling of rain water, snow melt and aerosol

\footnotetext{
* Geochemistry Research Association, Koenji-kita, Suginami, Tokyo, 166, Japan
}

in Tokyo was done during the period from June 1975 to the end of 1977.

Sampling was done at each rain and snow-fall by using rain pot made of polyvinyl chloride with $1 \mathrm{~m}^{2}$ which was installed in the test field in front of the laboratory (Geochemical Laboratory, Koenji-kita, Suginami, Tokyo). The sampling of aerosol was carried out by using a high volume sampler with a glass fiber filter. Usually, rain water of 5 liter and the air of $200 \mathrm{~m}^{3}$ were used for the analysis.

Immediately after sampling water, suspended matter was filtered through a filter paper. The determination of selenium in rain water and aerosol was carried out by the fluorometric method using Se(IV)-DAN complex dissolved in cyclohexane media. Intensity of fluorescence of Se(IV)-DAN complex extracted into a cyclohexane was measured at a wavelength of $520 \mathrm{~nm}$ with the exciting radiation of the wavelength of $375 \mathrm{~nm}$. Se(IV) is separated by the adsorption on the synthetic resin. $\mathrm{Se}(\mathrm{VI})$ and total Se were coprecipitated with tellurium. The detailed explanations of analytical procedures are described in another paper (Sugimura and Suzuki, 1977). In this paper, only a brief explanation on the analytical method are given. 
The total selenium (suspended + dissolved) were coprecipitated with tellurium in the presence of hydrazine sulfate as a reducing agent. The precipitate was dissolved in conc. $\mathrm{HNO}_{3}$ and evaporated nearly to dryness and the residue was dissolved again in $6 \mathrm{M} \mathrm{HC1}$ and boiled for three minutes. Selenium coprecipitated with tellurium was also converted finally to $\mathrm{Se}(\mathrm{IV})-\mathrm{DAN}$ complex.

The separation of $\mathrm{Se}(\mathrm{IV})$ and $\mathrm{Se}(\mathrm{VI})$ in rain water was done by the adsorption method of Se(IV)-DDTC complex on the XAD-2 resin. $\mathrm{Se}(\mathrm{IV})$ adsorbed on the XAD-2 resin was eluted by mixed solution of $\mathrm{HNO}_{3}$ and $\mathrm{HClO}_{4}$ and the effluent was evaporated nearly to dryness on a hot plate. The residue was analyzed with the same method as used for the total selenium.

$\mathrm{Se}(\mathrm{VI})$ which was not adsorbed on the XAD-2 resin and remained in the effluent was treated in the same way as in the case of the total selenium.

The residue on a filter paper was dissolved in nitric acid and the solution was evaporated nearly to dryness on a hot plate. The residue was analyzed with the same method as used for the total selenium.

The aerosol samples were dissolved in nitric acid on a hot plate and the solution was evaporated nearly to dryness and the residue was treated with HF solution, which was analyzed with the same method as used for the total selenium.

It was confirmed that the standard deviation of the analytical results is below $10 \%$.

\section{Results and discussions}

The results of analyses of selenium (Total Se, $\mathrm{Se}(\mathrm{IV})$ and $\mathrm{Se}(\mathrm{VI})$ ) in rain water and suspended matter are summarized in Table 1.

\subsection{The content and deposition of total selenium in rain water}

As seen in Table 1, the content of total selenium in rain water ranged from $5 \mathrm{ng} 1^{-1}$ to $118 \mathrm{ng}^{-1}$ with an average of $69 \mathrm{ng} 1^{-1}$.

No regular change was observed on the content of total selenium in rain water throughout a year. As seen in Fig. 1, there is an inverse correlation between the content of total selenium in rain water and an amount of rainfall.

Using an average of $69 \mathrm{ng} 1^{-1}$ of total selenium in rain water, the annual deposition of total selenium was estimated to be about $110 \mu \mathrm{g} \mathrm{m}^{-2}$ assuming the annual amount of rainfall of 1,600

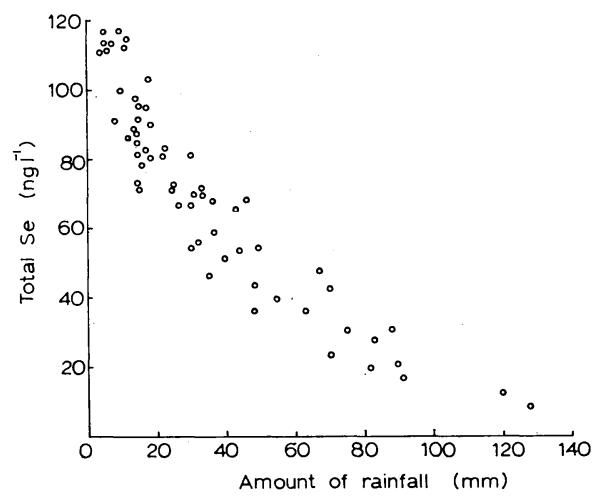

Fig. 1 The correlation between the content of total selenium in rain water and an amount of rainfall.

$\mathrm{mm}$. The amount of annual deposition of total selenium in Tokyo (Koenji) is a little larger than the value given by Rancitelli et al., (1970) in Quillayate, Wash., USA (about $70 \mu \mathrm{g} \mathrm{m}^{-2}, \mathrm{y}^{-1}$ ) and is much larger than that in Greenland or Antarctica ( 1 to $3 \mu \mathrm{g} \mathrm{m}^{-2}, \mathrm{y}^{-1}$; Weiss et al., 1971).

3.2 The content of selenium in rain water in different chemical forms

As given in Table 1, among different chemical forms of selenium in rain water, the tetravalent selenium is dominant, which ranged from $5 \mathrm{ng} 1^{-1}$ to $104 \mathrm{ng} 1^{-1}$ with an average of $49 \mathrm{ng} 1^{-1}$. On the other hand, the content of hexavalent selenium is less than $4 \mathrm{ng} 1^{-1}$ or even below a detection limit.

It is to be noticed that a content of selenium in suspended matter in rain water ranged from $6 \mathrm{ng} 1^{-1}$ to $38 \mathrm{ng} 1^{-1}$ with an average of $19 \mathrm{ng}$ $1^{-1}$. In order to clarify the chemical form of selenium in suspended matter, the method used by Andren et al., (1970) was used. It was found that selenium in suspended matter is dissolved in nitric acid, but it is not dissolved in hydrochloric acid. These result indicate that the chemical form of selenium in suspended matter may be in a metallic state.

On the basis of the above results, it is concluded that the chemical forms of selenium in rain water are tetravalent ions with a minute amount of hexavalent ions in a water phase and a metallic state in solid phase.

\subsection{Correlation between the content of selenium and other several metallic elements}

The correlation coefficient between content of selenium and other several metallic elements in 
Table 1 The Content of Selenium in Rain Water in Tokyo

\begin{tabular}{|c|c|c|c|c|c|c|c|c|c|}
\hline Date & $\begin{array}{c}\text { Amount of } \\
\text { rainfall } \\
(\mathrm{mm})\end{array}$ & Total & $\begin{array}{c}\text { Selenium } \\
\text { Se (IV) } \\
\left(n g 1^{-1}\right) \\
\end{array}$ & $\mathrm{Se}(\mathrm{O})$ & Date & $\begin{array}{l}\text { Amount of } \\
\text { rainfall } \\
(\mathrm{mm})\end{array}$ & Total & 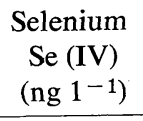 & $\mathrm{Se}(\mathrm{O})$ \\
\hline 1975 & & & & & 30 & 46.3 & 69 & 54 & 15 \\
\hline June 22 & 36.4 & 68 & & & Sept. 3 & 23.5 & 71 & 44 & 25 \\
\hline 26 & 15.4 & 85 & & & 8-9 & 30.3 & 55 & 50 & 14 \\
\hline July & 88.0 & 31 & & & 20 & 30.0 & 57 & 41 & 14 \\
\hline 6 & 33.0 & 57 & & & 27 & 27.2 & 50 & 38 & 10 \\
\hline 21 & 30.7 & 70 & & & Oct. 20 & 16.8 & 79 & 56 & 23 \\
\hline Aug. 18 & 35.5 & 59 & & & 24 & 24.0 & 71 & 41 & 28 \\
\hline 23 & 16.5 & 95 & & & Nov. 11 & 19.5 & 85 & 57 & 27 \\
\hline Sept. 5 & 17.3 & 87 & & & 14 & 19.8 & 82 & 55 & 25 \\
\hline 24 & 59.2 & 38 & 22 & 15 & Dec. 24 & 33.0 & 73 & 52 & 20 \\
\hline 29 & 33.4 & 57 & 41 & 14 & 1977 & & & & \\
\hline Oct. 3 & 16.5 & 79 & 68 & 10 & Jan. $26-27$ & 18.8 & 104 & 65 & 32 \\
\hline 5 & 90.0 & 21 & 12 & 8 & Feb. 10 & 12.0 & 112 & 72 & 36 \\
\hline 18 & 77.3 & 48 & 32 & 16 & 21 & 15.3 & 93 & 51 & 38 \\
\hline Nov. 1 & 44.4 & 66 & 58 & 7 & Mar. 17 & 28.2 & 84 & 57 & 24 \\
\hline 7 & 127.1 & 9 & 6 & & 23-24 & 38.1 & 67 & 43 & 20 \\
\hline 15 & 66.4 & 37 & 20 & 15 & 27 & 15.5 & 74 & 51 & 20 \\
\hline 19 & 29.7 & 81 & 68 & 11 & 30 & 83.0 & 28 & 10 & 15 \\
\hline 23 & 25.1 & 73 & 54 & 16 & Apr. 7-9 & 44.5 & 45 & 21 & 20 \\
\hline Dec. 8 & 47.8 & 44 & 28 & 15 & $12-13$ & 40.5 & 52 & 31 & 20 \\
\hline 1976 & & & & & 18 & 5.2 & 114 & 82 & 27 \\
\hline Feb. & 43.8 & 54 & 27 & 26 & $27-28$ & 5.9 & 112 & 91 & 19 \\
\hline 22 & 22.1 & 83 & 73 & 7 & May 4-5 & 15.4 & 96 & 63 & 30 \\
\hline 29 & 33.0 & 72 & 50 & 21 & 15 & 70.5 & 25 & 13 & 9 \\
\hline Mar. 12 & 10.0 & 118 & 93 & 24 & June $2-3$ & 15.5 & 81 & 54 & 25 \\
\hline 17 & 33.7 & 70 & 52 & 16 & 7 & 7.0 & 113 & 61 & 45 \\
\hline 29 & 11.0 & 86 & & & 10 & 12.0 & 115 & 70 & 41 \\
\hline 31 & 12.4 & 85 & & & $17-19$ & 75.0 & 31 & 21 & 10 \\
\hline Apr. 6 & 49.0 & 55 & 34 & 18 & $23-27$ & 81.5 & 20 & 10 & 8 \\
\hline 13 & 26.3 & 67 & 51 & 15 & July 1 & 3.5 & 111 & 104 & 7 \\
\hline $20-22$ & 13.8 & 98 & 83 & 14 & 7 & 30.0 & 64 & 41 & 20 \\
\hline $23-24$ & 19.0 & 91 & 78 & 13 & $11-12$ & 35.3 & 51 & 40 & 9 \\
\hline 30 & 34.8 & 48 & 40 & 7 & $16-17$ & 15.5 & 72 & 46 & 24 \\
\hline May 2 & 29.2 & 55 & 42 & 13 & Aug. 8-9 & 14.3 & 83 & 50 & 30 \\
\hline 16 & 30.5 & 56 & 45 & 11 & $13-15$ & 12.0 & 13 & 10 & \\
\hline 19 & 14.6 & 88 & 78 & 10 & 22 & 8.0 & 91 & 56 & 34 \\
\hline 25 & 56.0 & 40 & 23 & 16 & Sept. 8 & 4.8 & 117 & 78 & 32 \\
\hline June 5 & 30.0 & 67 & 41 & 25 & $8-15$ & 21.7 & 5 & 5 & \\
\hline 9 & 18.0 & 81 & 57 & 22 & $18-19$ & 38.0 & 43 & 27 & 12 \\
\hline 15 & 22.2 & 64 & 50 & 12 & $26-27$ & 13.0 & 87 & 52 & 35 \\
\hline 24 & 56.3 & 38 & 27 & 10 & 29 & 11.9 & 104 & 81 & 20 \\
\hline July 3 & 12.3 & 87 & 70 & 16 & Oct. $3-4$ & 50.0 & 43 & 31 & 10 \\
\hline $10-12$ & 67.0 & 42 & 35 & 6 & 11 & 5.7 & 93 & 64 & 27 \\
\hline $12-13$ & 10.5 & 100 & 79 & 20 & Nov. 4-5 & 7.8 & 102 & 71 & 30 \\
\hline $19-20$ & 24.3 & 81 & 59 & 20 & $16-17$ & 69.0 & 43 & 20 & 21 \\
\hline Aug. $\quad 9$ & 23.5 & 71 & 44 & 25 & $26-27$ & 18.1 & 90 & 63 & 26 \\
\hline $24-26$ & 27.8 & 68 & 56 & 10 & Dec. 17 & 43.6 & 52 & 37 & 12. \\
\hline 28 & 13.7 & 87 & 74 & 11 & & & & & \\
\hline
\end{tabular}

rain water is shown in Table 2. The correlation selenium and that of iron and aluminum is lower. coefficient between the content of selenium and 3.4 The content of selenium in aerosol in Tokyo that of copper, zinc and arsenic is higher, on The results of determination of content of the contrary, these between the content of selenium in aerosol in Tokyo was summarized 
Table 2 The Correlation Coefficient between Content of Selenium and Other Several Metallic Elements in Rain Water in Tokyo

\begin{tabular}{ccccccccc}
\hline Precipitation & $\mathrm{Fe}$ & $\mathrm{Al}$ & $\mathrm{Mn}$ & $\mathrm{Cu}$ & $\mathrm{V}$ & $\mathrm{Zn}$ & $\mathrm{As}$ & $\mathrm{Pb}$ \\
\hline 0.95 & 0.62 & 0.64 & 0.83 & 0.87 & 0.77 & 0.89 & 0.89 & 0.69 \\
\hline
\end{tabular}

Table 3 The Content of Total and a Water Soluble Part of Selenium in Aerosol in Tokyo (Koenji)

\begin{tabular}{|c|c|c|c|}
\hline \multirow{2}{*}{ Date } & \multirow{2}{*}{ Air volume } & \multicolumn{2}{|c|}{ Selenium $\left(\mathrm{ng} \mathrm{m}^{-3}\right)$} \\
\hline & & Total & Water soluble \\
\hline \multicolumn{4}{|l|}{1977} \\
\hline \multirow[t]{3}{*}{ Jan. } & 200 & 1.9 & 0.9 \\
\hline & 220 & 2.3 & 1.1 \\
\hline & 196 & 2.4 & 1.1 \\
\hline \multirow[t]{2}{*}{ Feb. } & 210 & 2.8 & 1.4 \\
\hline & 220 & 2.6 & 1.3 \\
\hline \multirow[t]{2}{*}{ Mar. } & 224 & 3.0 & 1.6 \\
\hline & 200 & 3.4 & 1.8 \\
\hline \multirow[t]{3}{*}{ Apr. } & 220 & 3.7 & 1.9 \\
\hline & 220 & 3.3 & 2.0 \\
\hline & 220 & 4.0 & 2.4 \\
\hline \multirow[t]{3}{*}{ May } & 220 & 4.2 & 2.6 \\
\hline & 210 & 3.8 & 2.3 \\
\hline & 200 & 3.6 & 2.1 \\
\hline \multirow[t]{3}{*}{ June } & 220 & 3.2 & 1.9 \\
\hline & 220 & 2.8 & 1.6 \\
\hline & 210 & 3.3 & 1.8 \\
\hline \multirow[t]{3}{*}{ July } & 220 & 3.0 & 1.8 \\
\hline & 210 & 3.3 & 1.9 \\
\hline & 210 & 2.7 & 1.6 \\
\hline \multirow[t]{2}{*}{ Aug. } & 200 & 2.2 & 1.3 \\
\hline & 224 & 1.7 & 0.9 \\
\hline \multirow[t]{2}{*}{ Sept. } & 220 & 2.1 & 1.0 \\
\hline & 220 & 3.6 & 1.9 \\
\hline \multirow[t]{2}{*}{ Oct. } & 210 & 3.5 & 1.9 \\
\hline & 210 & 3.2 & 1.6 \\
\hline \multirow[t]{3}{*}{ Nov. } & 210 & 2.9 & 1.5 \\
\hline & 220 & 2.4 & 1.2 \\
\hline & 220 & 3.3 & 1.7 \\
\hline \multirow{2}{*}{ Dec. } & 210 & 2.1 & 1.0 \\
\hline & 210 & 2.5 & 1.2 \\
\hline Average & & 3.0 & 1.6 \\
\hline
\end{tabular}

in Table 3. As shown in Table 3, the content of total selenium ranged from $1.7 \mathrm{ng} \mathrm{m}^{-3}$ to $4.2 \mathrm{ng} \mathrm{m}^{-3}$ with an average of $3.0 \mathrm{ng} \mathrm{m}^{-3}$. No regular change was observed on the content of total selenium in aerosol throughout a year in the same trend as in the case of the total selenium in rain water. These values of selenium content in aerosol in Tokyo is close to that given by Rancitelli et al., (1970) in New York City, N.Y. USA $\left(5.7 \mathrm{ng} \mathrm{m}^{-3}\right)$, but it is ten to fifty times higher than given by Duce et al., (1971) to the air over the Atlantic Ocean.
A water soluble part of selenium in aerosol was eluted with rain water ( $\mathrm{pH} 4$ to 5) and was separated into $\mathrm{Se}(\mathrm{IV})$ and $\mathrm{Se}(\mathrm{VI})$ using XADDDTC method. As a result, it was found that the chemical form in a water soluble part of selenium in aerosol is tetravalent ion, and its ratio to total is 0.5 to 0.6 . On the other hand, the chemical form of a water insoluble part of selenium in aerosol may be a metallic state, because selenium retained on a filter paper can be dissolved in nitric acid (Andren et al., 1970).

\subsection{The sources of selenium in the air}

Main sources of selenium in urban atmosphere may be combustion products of fossil fuels. There is also another source of selenium containing in a soilly matter, however, it is estimated to be below $5 \%$ of the total, on the basis of the content of aluminum in rain water in Tokyo.

According to Andren et al., (1970), the chemical form of selenium emitted to the atmosphere through combustion of fossil fuels is estimated to be $\mathrm{Se}(0)$ and $\mathrm{SeO}_{2}$. The results of study by the present authors also support the view by Andren et al., (1970).

\section{Acknowledgements}

The authors wish to express their thanks to Dr. K. Saruhashi, Geochemistry Research Association (the former Director of the Geochemical Research Division of the Meteorological Research Institute), for helpful discussions and suggestions.

\section{References}

Andren, A. W., D. H. Kline and Y. Talmi, 1970: Selenium in coal-fired steam plant emissions. Environ. Sci. Tech., 9, 856-858.

Bertine, K. K., E. D. Goldberg, 1971: Fossil fuel combustion and the major sedimentary cycle. Science, 173, 233-235.

Duce, R. A., G. L. Hoffman and W. H. Zoller, 1971: Atmospheric trace metals at northern and southern hemisphere. Science, 107, 59-61.

Hashimoto, Y. and J. W. Winchester, 1971: Selenium in the atmosphere. Environ. Sci. Tech., 4, 157158.

Miyake, Y., K. Saruhashi and Y. Katsuragi, 1959: The Sr-90 fallout and the air motion, Pap. Met. 
Geophys., 9, 172-176.

Rancitelli, L. A. and R. W. Perkins, 1970: Trace element concentration in the troposphere and lower stratosphere. J. Geophys. Res., 75, 30553064.

Sugimura, Y. and Y. Suzuki, 1977: A new fluoro- metric method of analysis of selenium in sea water. J. Oceanogr. Soc. Japan, 33, 23-29.

Weiss, H. V., M. Koide and E. D. Goldberg, 1971: Selenium and sulfur in Greenland ice sheet: relation to fossil fuel combustion. Science, 172, 261-263.

\title{
東京における降水·エーロゾル中のセレン含量と \\ 化学形について
}

\author{
鈴 木款, 杉 村 行 勇 \\ 気象研究所 \\ 三 $\underset{\text { 宅地球化学研究協会 }}{\text { 雄 }}$
}

1975年 6 月から1977年末までの期間に，東京（高円寺）に拈いて採取した降水とエーロゾル中のセレン含量と その化学形の研究を行なった。セレンの分析は, 䖝光法を用いた。降水の全セレン含量は $5 \sim 118 \mathrm{ng} l^{-1}$ で, 平

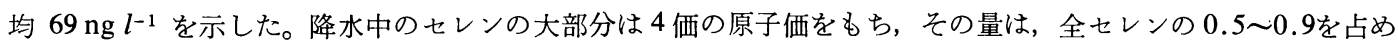
る。残りのセレンは粒子状で存在することがわかった。また，東京に打けるエーロゾル中のセレン含量は 1.7〜 $4.2 \mathrm{ng} \mathrm{m}^{-3}$ で, 平均 $3.0 \mathrm{ng} \mathrm{m}^{-3}$ であった。エーロゾルの水溶性部分に含まれるセレンの化学形は 4 価イオンで

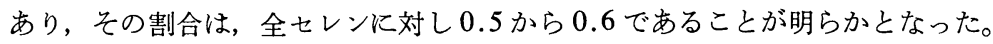

